\title{
Kompabilitas Penggunaan Metode Omnibus Dalam Pembentukan Undang-Undang
}

\author{
Ibnu Sina Chandranegara \\ Fakultas Hukum Universitas Muhammadiyah Jakarta \\ Jln. KH. Ahmad Dahlan, Cirendeu, Jakarta Selatan, 15419 \\ ibnusinach@gmail.com
}

Received: 30 Maret 2020; Accepted: 11 Juni 2020; Published: 25 Agustus 2020

DOI: 10.20885/iustum.vol27.iss2.art2

\begin{abstract}
Each legal system has its own theory of statutory formation, both countries that apply civil law and common law legal systems. The tendency to form laws in Indonesia after the realization of the need for regulatory reform has resulted in a growing awareness of making breakthroughs by using the omnibus method which is generally applicable in countries that apply the common law system. The question is whether this method is suitable to be adopted into the legal system of Indonesia? This article intends to examine the compatibility of the omnibus method and the solutions that need to be used to overcome its compatibility problems. This research concludes that if Indonesia is to adopt the omnibus method, it also requires a consolidation method before and after the enactment of legislation with the omnibus method, this is intended to consolidate it with the affected legislation.
\end{abstract}

Key Words: Omnibus method; statutory formation; compatibility

\begin{abstract}
Abstrak
Setiap sistem hukum memiliki teori pembentukan perundang-undangannya sendiri, baik negara yang menggunakan sistem hukum civil law maupun common law. Kecenderungan pembentukan undangundang di Indonesia setelah disadari perlunya reformasi regulasi mengakibatkan tumbuhnya kesadaran untuk melakukan terobosan dengan digunakannya metode omnibus yang umumnya berlaku di negara yang menggunakan sistem common law. Persoalannya apakah metode ini cocok diadopsi ke dalam sistem perundang-undangan di Indonesia? Artikel ini bermaksud meneliti kompabilitas metode omnibus dan solusi yang perlu digunakan untuk menanggulangi persoalan kompabilitasnya. Penelitian ini menghasilkan kesimpulan bahwa apabila Indonesia akan mengadopsi metode omnibus, maka diperlukan pula metode konsolidasi pada undang-undang (UU) sebelum atau pasca UU dengan metode omnibus, hal ini dimaksudkan mengkonsolidasikannya dengan UU terdampak.
\end{abstract}

Kata-kata Kunci: Metode omnibus; pembentukan undang-undang; kompabilitas 


\section{Pendahuluan}

Kebutuhan akan reformasi regulasi di Indonesia disadari oleh karena membengkaknya jumlah regulasi yang dipersepsikan tidak memudahkan dalam berusaha dan mendukung iklim investasi. ${ }^{1}$ Di saat yang bersamaan, situasi semakin memburuk disebabkan data peraturan perundang-undangan kerapkali tidak sama antara pengelola data yang satu dengan pengelola data yang lain. ${ }^{2}$ Persoalan bawaan lainnya yaitu belum ada lembaga yang merupakan pengelola tunggal data peraturan perundang-undangan yang resmi. ${ }^{3}$ Meningkatnya peran pengadilan dalam menentukan validitas setiap regulasi maupun kebijakan negara, ${ }^{4}$ menunjukan bahwa regulasi di Indonesia mengalami persoalan akut yang harus diselesaikan segera.

Kondisi sebagaimana terurai di atas, memunculkan beragam motivasi dan tindakan reformasi regulasi yang sekurang-kurangnya memiliki tiga bentuk. Pertama, pembentuk undang-undang memiliki motivasi untuk menghapuskan sistem saat ini ada dan ingin memulai membentuk sistem yang baru. Kedua, pembentuk undang-undang memiliki motivasi untuk mereformasi sistem pembentukan undang-undang secara komprehensif bahkan melakukan transplantasi. Ketiga, pembentuk undang-undang memiliki motivasi untuk mereformasi sistem pembentukan undang-undang namun tanpa melakukan tindakan radikal. Motivasi sebagaimana dikemukakan di atas ditunjukan dengan

${ }^{1}$ Kurun waktu 2000-2017 terdapat 35.901 peraturan, jumlah terbanyak adalah Peraturan Daerah (Perda) yaitu sebanyak 14.225 Perda, disusul dengan Peraturan Menteri (Permen) sebanyak 11.873 Permen, dan di tempat ketiga diduduki peraturan lembaga non kementerian sebanyak 3.163 peraturan. Masih tercatat pula peraturan peninggalan Penjajah Belanda sebanyak 36 peraturan. Jumlah kuantitas yang demikian itu tidak berjalan lurus dengan kualitas regulasi. Hal ini nampak dari banyaknya kaidah-kaidah hukum yang timbul dari proses pengujian norma di kekuasaan kehakiman. Tercatat, hingga Maret 2017 terdapat 802 putusan Mahkamah Konstitusi, 203 Putusan Mahkamah Agung, dan kaidah hukum melalui menafsiran hukum seperti yang terdapat dalam putusan pengadilan niaga yang berjumlah 168 putusan. Ibnu Sina Chandranegara, "Bentuk-Bentuk Perampingan dan Harmonisasi Regulasi”, Jurnal Hukum Ius Quia Iustum Vol. 26. No. 3, 2019, hlm. 435.

2 Wicipto Setiadi, Simplifikasi Regulasi Melalui Pendekatan Omnibus Law: Suatu Keniscayaan, Orasi Ilmiah Dalam Rangka Dies Natalis Universitas Pembangunan Nasional "Veteran” Jakarta Ke-57, 7 Januari 2020, hlm. 2.

${ }^{3}$ Wicipto Setiadi, "Menggagas Undang-Undang Sapu Jagat", Koran Seputar Indonesia, 5 November 2019.

${ }^{4}$ Dejonghe Matthias menyebutnya dengan countermajoritarian difficulty, dengan disediakannya mekanisme judicial review maka akan mendorong segala pengujian validitas kebijakan regulasi negara melalui peradilan. Hal ini sebagaimana yang diungkapkannya "Judicial review is countermajoritarian because it allows judges to thwart the will of the majority. It enables decisions by the legislature to be overturned by a small minority, through judgments". Dejonghe Matthias, Constitutional Courts: Democracy vs. Juristocracy?, Disertasi, Fakultas Hukum Universitas Genht, Brussel, 2015, hlm. 4-5. 
kebijakan Presiden menyatakan memilih menggunakan transplantasi metode omnibus untuk mereformasi regulasi. ${ }^{5}$

Kebijakan yang kemudian populer dengan nama omnibus law, bahkan tidak hanya dimaksudkan hanya satu rancangan undang-undang (RUU) saja, melainkan 4 RUU sekaligus, antara lain (1) penciptaan lapangan pekerjaan, (2) perpajakan, dan (3) ibu kota negara. Sedangkan muncul perencanaan bahwa dari pihak legislatif akan diterbitkan Rancangan Undang-Undang (RUU) Omnibus di bidang farmasi. ${ }^{6}$ Akan tetapi, Rencana ambisius tersebut mendapat resistensi dalam tataran konsep kebijakan maupun implementasinya disebabkan dengan adanya anggapan bertentangan dengan sistem hukum yang dianut. Namun, mayoritas kritik justru ditujukan secara kepada substansi RUU tentang Cipta Kerja yang menggunakan metode omnibus yang "dikebut" dan saat ini telah bola panas berada di tangan DPR.7

\section{Rumusan Masalah}

Berdasarkan latar belakang tersebut, maka penelitian ini memiliki rumusan masalah sebagai berikut. Pertama, bagaimanakah kompabilitas penggunaan metode omnibus dalam pembentukan undang-undang? Kedua, perubahanperubahan apa sajakah yang perlu dilakukan apa bila penggunaan metode omnibus digunakan, untuk dapat menyesuaikan sistem perundang-undangan di Indonesia?

\section{Tujuan Penelitian}

Penyusunan penelitian ini bertujuan sebagai berikut: pertama, mengukur kompabilitas penggunaan metode omnibus dalam pembentukan undang-undang dengan sistem perundang-undangan dan hukum yang dianut di Indonesia. Kedua, menemukan perubahan dan penyesuaian yang perlu diadakan dalam hal metode omnibus diterapkan ke dalam pembentukan undang-undang di Indonesia.

\footnotetext{
${ }^{5}$ Cara yang dipilih ini bahkan disampaikan dalam Pidato Pelantikan pada periode jabatan yang baru, meskipun tahapan persiapan untuk mempersiapkan rancangan undang-undang (RUU) menggunakan metode omnibus telah dilakukan sebelum Pemilu Presiden 2019. Bobby Gafur Umar, Omnibus Law guna Menjawab Tantangan dan Peluang Pertumbuhan Ekonomi, Makalah dalam Seminar Dies Natalis Fakultas Hukum UGM, 13 Februari 2020, hlm. 2.

${ }^{6}$ Ibid., hlm. 3

${ }^{7}$ RUU Cipta Kerja telah disampaikan kepada DPR melaui Surat Presiden No R-06/Pres/02/2020 tanggal 7 Februari 2020.
} 


\section{Metode Penelitian}

Penelitian ini merupakan penelitian yuridis normatif. Data yang digunakan adalah data sekunder yang meliputi bahan hukum primer dan sekunder berupa peraturan perundangan maupun rancangan undang-undang yang sesuai dengan konteks. Data sekunder diperoleh melalui studi pustaka. Metode pendekatan yang digunakan adalah conceptual approach dan statue approach. Analisis data dilakukan dengan mensistematisasi data-data untuk selanjutnya data-data tersebut digunakan untuk menerjemahkan konsep yang tepat dalam dalam hal mengkalibrasi metode omnibus dalam penyusunan undang-undang di Indonesia.

\section{Hasil Penelitian dan Pembahasan}

\section{Meninjau Kompabilitas Metode Omnibus}

Dalam sistem hukum Indonesia, A. Hamid S. Attamimi menjelaskan bahwa perundangan-undangan di Indonesia bersifat normatif-kognitif yang mencakup 3 ranah penting: proses perundang-undangan; metode perundang-undangan dan teknik perundang-undangan. ${ }^{8}$ Selain itu, perundangan-undangan juga harus taat asas hukum (rechtsbeginsel). Walaupun asas hukum bukanlah aturan hukum (rechtsregel), namun hukum tidak akan dapat dipahami tanpa asas-asas hukum. Van der Vlies membagi asas-asas peraturan perundang-undangan menjadi asasasas hukum yang formal dan yang material. ${ }^{9}$

Dalam sistem perundang-undangan nasional, UU dipahami tidak semata produk politik, namun juga merupakan manifestasi ketaatan asas hukum yang diatur secara hierarkis yang kemudian dikenal sebagai teori hukum berjenjang (die theorie vomstufenordung der rechtsnormen) yang dikembangkan Hans Nawiasky. ${ }^{10}$ Di sisi lain, Hans Kelsen kemudian menyebutnya sebagai teori

8 A. Hamid S. Attamimi dalam Maria Farida Indrati, Ilmu Perundang-undangan: Proses dan Teknik Penyusunan Kanisius, Yogyakarta, 2007, hlm. 229.

${ }^{9}$ Asas-asas hukum formal yang meliputi: (1). Asas tujuan yang jelas; (2). Asas organ/lembaga yang tepat; (3). Asas perlunya pengaturan; (4). Asas dapatnya dilaksanakan; (5). Asas konsensus. Asas-asas hukum material yang melingkupi: (1). Asas tentang terminologi dan sistematika yang benar; (2). Asas tentang aturan yang dapat dikenali; (3). Asas perlakuan yang sama dalam hukum; (4). Asas kepastian hukum; (5). Asas pelaksanaan hukum sesuai keadaan individual. I.C van der Vlies, Buku Pegangan Perancang Peraturan Perundang-Undangan, Direktorat Jenderal Peraturang Perundang-undangan, Jakarta, 2005, hlm. 238-307.

${ }^{10}$ Hans Kelsen, The Pure Theory of Law, University of California Press, California, 1967, hlm. 1-3. 
validasi norma hukum (validity of legal norm theory). ${ }^{11}$ Dalam konteks Indonesia sendiri, A. Hamid Attamimi ${ }^{12}$ dan Maria Farida Indrati ${ }^{13}$ memberi mengelaborasi teori di atas dengan memberi sentuhan khas norma Indonesia baik dalam groundnorm maupun rechtsidee, antara lain, pertama, cita hukum (rechtsidee), yaitu Pancasila, dimana sila-sila Pancasila berlaku sebagai 'bintang pemandu' dalam bernegara; kedua, norma fundamental negara yakni Pancasila, dimana sila-sila Pancasila berlaku sebagai norma dasar; ketiga, Asas-asas negara berdasarkan atas hukum yang menempatkan UU sebagai alat pengaturan yang khas berada dalam keutamaan hukum (der Primat des Rechts) yang artinya UU turunan utama undang-undang dasar; keempat, asas-asas pemerintahan berdasarkan sistem konstitusi (konstitusionalisme) yang menempatkan UU sebagai dasar dan batas penyelenggaraan kegiatan-kegiatan pemerintah. ${ }^{14}$

Dalam konteks sebagaimana di atas, sistem perundang-undangan nasional sesungguhnya juga telah menganut konsep the single subject rule atau The One Subject at a Time Act yaitu metode yang mengatur tentang satu subyek dalam satu undang-undang. ${ }^{15}$ Metode ini secara tidak langsung sama dengan metode yang digunakan di Indonesia sebagaimana ditentukan dalam BAB I huruf A angka 6 dan 7 Lampiran II UU No. 12 Tahun 2011 tentang Pembentukan Peraturan Perundang-Undangan yang menjelaskan tentang tata cara penanamaan subjek yang diatur, temasuk bentuk penamaan perubahannya hanya penyangkut subyek yang telah diatur sebelumnya:

1 Pada nama Peraturan Perundang-undangan perubahan ditambahkan frasa perubahan atas di depan judul Peraturan Perundang-undangan yang diubah

11 Giorgio Bongiovanni memberikan pandangannya terhadap teori validasi, "Kelsen's normative theory, in contrast to Austin, dealt with legal validity that starts at the bottom and rises to the pinnacle of the law. Subordinate laws must normatively correspond to upper and supreme law, which is the constitution, and to abstract legal norm namely Grundnorm." Giorgio Bongiovanni, "Rechsstaat and Grundnorm in the Kelsenian Theory", dalam Marijan Pavčnik dan Gianfransesco Zanetti, Legal System and Legal Science, Proceeding of $17^{\text {th }}$ World Congress of The International Association For Philosophy of Law and Social Philosophy, Bologna, Italia, 16- 21 June 1995, hlm. 65.

12 A. Hamid S. Attamimi, Peranan Keputusan Presiden Republik Indonesia dalam Penyelenggaraan Pemerintahan Negara: Suatu Studi Analisis Mengenai Keputusan Presiden yang Berfungsi Pengaturan Dalam Kurun Waktu PELITA I-PELITA IV, Disertasi, Fakultas Hukum Universitas Indonesia, 1990, hlm. 46.

13 Maria Farida Indrati, Dapatkah Undang-Undang Omnibus menyelesaikan masalab tumpang tindihnya undangundang?, Bahan Rapat Dengar Pendapat Umum Badan Legislasi DPR-RI, 2 Desember 2020, hlm. 1.

${ }^{14}$ Pasal 5 UU Nomor 12 Tahun 2011 tentang Pembentukan Peraturan Perundang-undangan.

${ }_{15}$ Michael D. Gilbert, "Single Subject Rules And The Legislative Process", University Of Pittsburgh Law Review Vol. 67, No 4, 2006, hlm. 804. 
2 Jika Peraturan Perundang-undangan telah diubah lebih dari 1 (satu) kali, di antara kata perubahan dan kata atas disisipkan keterangan yang menunjukkan berapa kali perubahan tersebut telah dilakukan, tanpa merinci perubahan sebelumnya"

Penggunaan metode the single subject rule dilakukan untuk mencegah penyalahgunaan kekuasaan pembentuk undang-undang untuk melanggar hak privat atau apa yang dikemukakan Millard H. Ruud sebagai to combat various forms of legislative misconduct. ${ }^{16}$ Lebih jauh, Richard Briffault mengemukakan bahwa hingga 2019, 43 Konstitusi negara bagian di Amerika Serikat telah menetapkan single subject rule. Bahkan sebagian besar telah diatur sejak abad ke19. ${ }^{17}$ Sebagai contoh Pasal 15 (A) bab Passage of Bill dalam Louisiana State Constitution, menentukan"Every bill, except the general appropriation bill and bills for the enactment, rearrangement, codification, or revision of a system of laws, shall be confined to one object." 18 Meskipun metode the single subject rule diterapkan untuk menghindari penggunaan metode omnibus yang dianggap tidak demokratis, ${ }^{19}$ namun pada kondisi terkini, dorongan pembentukan undang-undang dengan penggunaan metode omnibus meningkat. Bahkan, apabila merujuk kepada praktik penerbitan Peraturan Pemerintah Pengganti Undang-Undang No. 1 Tahun 2020 tentang Kebijakan Keuangan Negara Dan Stabilitas Sistem Keuangan Untuk Penanganan Pandemi Corona Virus Disease 2019 (Covid-19) dan/atau Dalam Rangka Menghadapi Ancaman Yang Membahayakan Perekonomian Nasional dan/atau Stabilitas Sistem Keuangan, terdapat Pasal 28 yang memuat ketentuan yang menyatakan tidak berlakunya 12 undang-undang sepanjang terkait dengan kebijakan yang ditentukan dalam Perppu No. 1 Tahun 2020 tersebut. ${ }^{20}$ Artinya,

${ }^{16}$ Millard H. Ruud, "No Law Shall Embrace More Than One Subject", Minnesota Law Review Vol. 42 No. 1, 1958, hlm. 385.

${ }^{17}$ Richard Briffault, "The Single-Subject Rule: A State Constitutional Dilemma", Albany Law Review, Vol. 82 No. 4, 2019, hlm. 1629.

${ }^{18}$ Ibid., hlm. 1630

${ }_{19}$ Adam M. Dodek, “Omnibus Bills: Constitutional Constraints and Legislative Liberations", Ottawa Law Review Vol. 48, No. 1, 2017, hlm. 8.

2012 ketentuan tersebut antara lain: pertama, ketentuan jangka waktu yang diatur dalam Pasal 11 ayat (21, Pasal 17b ayat (1), Pasal 25 ayat (3), Pasal 26 ayat (1), dan Pasal 36 ayat (1c) UU No 6 Tahun 1983 tentang Ketentuan Umum Dan Tata Cara Perpajakan jo UU No 16 Tahun 2009 tentang Penetapan Peraturan Pemerintah Pengganti Undang-Undang No. 5 Tahun 2008 tentang Perubahan Keempat Atas UU No 6 Tahun 1983 tentang Ketentuan Umum Dan Tata Cara Perpajakan Menjadi Undang-Undang; Kedua, Pasal 55 ayat (4) UU No. 23 Tahun 1999 tentang Bank Indonesia Jo Undang-Undang No. 6 Tahun 2009 tentang Penetapan Peraturan Pemerintah Pengganti Undang-Undang No. 2 Tahun 2008 tentang Perubahan Kedua Atas UndangUndang No. 23 Tahun 1999 tentang Bank Indonesia menjadi Undang-Undang; Ketiga, Pasal 12 ayat (3) beserta 
dengan Perppu ini, ketentuan pasal-pasal yang tersebut dalam ke-12 undangundang itu ditangguhkan atau dikesampingkan berlakunya untuk sementara waktu, hingga tujuan tercapai atau krisis Covid-9 dinyatakan sudah berakhir. Apabila ditinjau berdasarkan jangkauan normatif yang dicakup di dalamnya, tanpa harus diterangkan secara panjang lebar lagi, Perppu No. 1 Tahun 2020 ini dapat dikatakan sudah menerapkan metode omnibus. Praktik metode omnibus yang telah dimunculkan dalam Pasal 28 Perppu No 1 Tahun 2020 tersebut, pada akhirnya membuat saya menguji Pasal 28 Perppu No 1 Tahun 2020 tersebut dan hingga saat ini naskah ini disusun, masih tahap pengujian di Mahkamah Konstitusi dengan No. Perkara 23/PUU-XIII/2020, meskipun Perppu No. 1 Tahun 2020 telah disetujui DPR pada 12 Mei 2020, disahkan Presiden 16 Mei 2020, dan diundangkan menjadi UU No. 2 Tahun 2020 pada 18 Mei 2020.

Apabila meninjau segi konseptual, sejatinya, pengadopsian metode omnibus dapat ditinjau dari kajian perbandingan hukum. Doktrin yang dikenal adalah doktrin transplantasi hukum (legal transplant) yang memiliki konten yang relevan dan bahkan sudah memprediksi akan adanya celah epistimologis dan praktis dalam studi perbandingan hukum. Alan Watson menjelaskan bahwa setidaknya terdapat dua tantangan dalam proses transplantasi hukum, yaitu: resepsi dalam hukum (reception in law) and resepsi dalam masyarakat (reception in society), ${ }^{21}$ Lebih jauh Alan Watson, mengemukan tiga relevansi dari tranplantasi hukum. Pertama, transplantasia dalam metode perkembangan hukum yang umum dan

penjelasannya, Pasal 15 ayat (5), Pasal 22 ayat (3), Pasal 23 ayat (1), Pasal 27 ayat (3), dan Pasal 28 ayat (3) dalam UU No. 17 Tahun 2003 tentang Keuangan Negara; Keempat, Pasal 3 ayat (3) UU No. 1 Tahun 2004 tentang Perbendaharaan Negara. Kelima, Pasal 22 ayat (2) dan ayat (3) UU No. 24 Tahun 2004 tentang Lembaga Penjamin Simpanan Jo UU No. 7 Tahun 2009 tentang Penetapan Peraturan Pemerintah Pengganti UndangUndang No. 3 Tahun 2008 tentang perubahan atas Undang-Undang No. 24 Tahun 2004 tentang Lembaga Penjamin Simpanan menjadi Undang-Undang; Keenam, Pasal 27 ayat (1) beserta penjelasannya, Pasal 36, Pasal 83, dan Pasal 107 ayat (2) UU No. 33 Tahun 2004 tentang Perimbangan Keuangan Antara Pemerintah Pusat dan Pemerintahan Daerah; Ketujuh, Pasal 171 UU No. 36 Tahun 2009 tentang Kesehatan; Kedelapan, Pasal 72 ayat (2) beserta penjelasannya UU No. 6 Tahun 2014 tentang Desa; Kesembilan, Pasal 316 dan Pasal 317 UU No. 23 Tahun 2014 tentang Pemerintahan Daerah Jo UU No. 9 Tahun 2015 tentang Perubahan Kedua atas UndangUndang Nomor 23 Tahun 2014 tentang Pemerintahan Daerah; Kesepuluh, Pasal 177 huruf c angka 2, Pasal 180 ayat (6), dan Pasal 182 UU No. 17 Tahun 2014 tentang Majelis Permusyawaratan Rakyat, Dewan Perwakilan Rakyat, Dewan Perwakilan Daerah, Dan Dewan Perwakilan Rakyat Daerah Jo UU No. 13 Tahun 2019 tentang Perubahan Ketiga atas Undang-Undang Nomor 17 Tahun 2014 tentang Majelis Permusyawaratan Rakyat, Dewan Perwakilan Rakyat, Dewan Perwakilan Daerah, dan Dewan Perwakilan Rakyat Daerah; Kesebelas, Pasal 20 ayat (2) dan ayat (3) UU No. 9 Tahun 2016 tentang Pencegahan dan Penanganan Krisis Sistem Keuangan; dan Keduabelas, Pasal 11 ayat (22), Pasal 40, Pasal 42, dan Pasal 46 UU Nomor 20 Tahun 2019 tentang Anggaran Pendapatan Dan Belanja Negara Tahun Anggaran 2020.

21 Alan Watson, Legal Transplant: an Approach to Comparative Law, University of Georgia Press, 1974, hlm. 12 
mudah, sehingga bukan hal yang tidak lazim dalam perkembangan hukum. ${ }^{22}$ Kedua, nyatanya banyak hukum yang dianut membutuhkan perkembangan untuk menyesuaikan kebutuhan dan perkembangan global. ${ }^{23}$ Ketiga, pembentukan hukum sejatinya produk yang dibentuk oleh kelompok elit yang diwakili oleh pemerintah, politisi, pengacara, hakim dan akademisi hukum yang kebutuhannya tercermin dalam hukum tetapi bukan kebutuhan masyarakat atau elit penguasa, sehingga transplantasi berada di dalam proses yang kedap tersebut. ${ }^{24}$ Sebaliknya, Pierre Legrand justru banyak mengkritik doktrin transplantasi hukum dengan mengemukakan, transplantation of law is not possible at all because every law is culturally determined. ${ }^{25}$ Pengaruh kultur yang tidak akan pernah sama menurutnya akan menghilangkan makna dalam sistem hukum yang dianut di suatu negara. Pierre Legrand menyebutnya sebagai no form of words purporting to be a "rule" can be completely devoid of semantic content, for no rule can be without meaning. ${ }^{26}$ Fondasi berpikir yang demikian itu melahirkan kesimpulan the meaning of law in different cultures can never be the same -'meaning cannot survive the journey' and transplantation is impossible as such. ${ }^{27}$ Kedua pandangan inilah yang kemudian disebut sebagai perdebatan transferists versus culturalist. ${ }^{28}$ Terlepas dari perdebatan filosofis dan epistimologis di atas, perbandingan hukum telah mendapatkan pengakuan internasional sebagai sebuah pendekatan penelitian hukum. Konrad Zweigert dan H. Kötz mengetengahkan tesis fungsi dan masalah dalam pengaplikasian perbandingan hukum. Keduanya berpendapat bahwa perbandingan hukum juga memiliki limitasi yakni; dua atau lebih obyek yang diperbandingkan haruslah memiliki fungsi dan peran konstitutional yang sama, selain itu obyek-obyek kajian tersebut haruslah memiliki permasalahan yang ingin dicapai yang sama. ${ }^{29}$

\footnotetext{
22"transplanting is, in fact, the most fertile source of development. Most changes in most systems are the result of borrowing". Alan Watson, "Aspects of Reception of Law", The American Journal of Comparative Law Vol. 44. 1996, hlm. 335.

23 "to an extent which renders implausible the existing theories of legal development and of the relationship between law and society. Alan Watson, "Legal Change: Sources of Law and Legal Culture", University of Pennsylvania Law Review, Vol. 131, No. 5 (1983) hlm. 1121.

${ }^{24}$ Alan Watson, "Society and Legal Change", Michigan Law Review Vol. 78, No. 5, 1980, hlm. 831.

25 Pierre Legrand 'What Legal Transplants?, dalam David Nelken dan Johannes Feest, eds., Adapting Legal Cultures, Hart Publishing, Oxford, Portland, Oregon, 2001, hlm. 56-57.

${ }^{26}$ Ibid., hlm. 58

${ }^{27}$ Ibid

${ }^{28}$ Nicholas H.D. Foster, Company Law Theory in Comparative Perspective: England and France, The American Journal of Comparative Law Vol. 48, No. 4, 2000, hlm. 573-621. hlm. 36 .

${ }^{29}$ Konrad Zweigert \& H. Kötz, An Introduction of Comparative Law, Oxford University Press, Oxford, 1998,
} 
Mark Tushnet menambahkan bahwa dalam peraturan konstitusi masing-masing negara pasti memiliki penyusunan fungsi-fungsi yang berbeda. Tugas dari peneliti perbandingan hukum adalah untuk mengidentifikasikan kesamaan baik minor maupun mayor (walaupun pasti ada perbedaan) dalam fungsi entitas hukum yang dikaji dan menganalisasi bagaimana fungsi tersebut diharapkan dapat menyelesaikan masalah. ${ }^{30}$

Sebelum penulis menilai kompabilitasnya, maka dikemukakan setidaktidaknya terdapat pihak yang mendukung dan keberatan terhadap penggunaan metode omnibus. Misalnya Jimly Asshidiqie, mendukung penggunaan metode omnibus dikarenakan menurutnya, dewasa ini sedang terjadi eksekutivisasi sistem legislasi di negara-negara 'civil law', dan kecenderungan legislativisasi pembentukan UU dalam praktik di negara-negara 'common law'. 31 Di samping itu, Ahmad Redi, berpandangan bahwa penggunaan metode omnibus meningkatkan kecepatan dalam penyusunan sebuah UU karena dengan menyusun sebuah Omnibus Law dapat sekaligus mengkoreksi UU existing yang dianggap bermasalah. ${ }^{32}$

Berbanding terbalik dengan dua pendapat tersebut, Adam Dodek, mengemukakan setidaknya 3 keberatan penerapan metode omnibus, pertama, mendudukan parlemen menjadi tidak berdaya dan sulit meminta pertanggungjawaban pemerintah; kedua, menyulitkan untuk anggota parlemen "meneliti" dengan seimbang dengan pemerintah; dan ketiga, adanya kesan radikal dari metode omnibus karena tidak hanya menghapus suatu UU namun juga memunculkan norma hukum baru yang menegasikan norma hukum yang lama.

${ }^{30}$ Mark Tushnet, “The Possibilities of Comparative Law”, Yale Law Review Vol. 108, 1999, hlm. 1225.

${ }^{31}$ Karena itu, dewasa ini, produksi UU di negara-negara 'common law' meningkat tajam melebihi produksi UU di negara-negara 'civil law' yang sistem hukumnya dapat dikatakan sudah relatif stabil dan ajeg. Karena itu, Negara Hukum Indonesia sudah seharusnya mengurangi ketergantungan pada pembentukan UU dengan lebih meningkatkan kedudukan, peran, dan kualitas yudisprudensi dalam aneka penyelesaian masalah-masalah hukum dalam praktik. Bersamaan dengan itu, timbul pula kecenderungan pengutamaan peran pengawasan oleh parlemen dibandingkan peran legislasi, sehingga perancangan UU dapat diidealkan agar dipersiapkan atas inisiatif pemerintah, tetapi peran pengawasan DPR dapat semakin ditingkatkan dengan efektif, baik pengawasan dalam pembentukan UU (legislative acts), dan pengawasan terhadap pembentukan peraturan-peraturan pelaksanaan UU (executive acts), maupun pengawasan terhadap implementasi UU dan pengawasan pelaksanaan program-program kerja pembangunan yang dibiayai oleh APBN dalam rangka pelaksanaan peraturan perundang-undangan (executive actions). Jimly Asshiddiqie, UU Omnibus (Omnibus Law), Penyederhanaan Legislasi, dan Kodifikasi Administratif, tanpa tahun, tanpa penerbit, hlm. 5.

32 Ahmad Redi, Omnibus Law Gasasan Pengaturan untuk. Kemakmuran Rakyat, Bahan Presentasi Diskusi Kolegium Jurist Institute, Rambu-Rambu Konstitusi dalam Wacana Omnibus Law, Jakarta 5 Maret 2020, hlm. 14. 
Metode ini dikesankan hanya untuk efesiensi. ${ }^{33}$ Ketiganya disimpulkan oleh Adam Dodek sebagai metode yang abusive dan dalam ungkapan lain oleh Adam Dodek sebagai threatens its (Parliament-Penulis) autonomy and powers in the long term. ${ }^{34}$

Apabila kompabilitas ditinjau dari segi definisi, maka "omnibus" dimaknai sebagai relating to or dealing with numerous objects or items at once; including many things or having various purposes. ${ }^{35}$ Definisi di atas menujukan bahwa produk hukum dengan metode omnibus akan mengenyampingkan beberapa undangundang yang terkait dan beririsan dengan satu sama lainnya. Penyampingan beberapa undang-undang dilakukan agar tujuan dari pembuatan undang-undang dengan metode omnibus dapat tercapai tanpa biaya yang besar. ${ }^{36}$ Sedangkan apabila meninjau definisi peraturan perundang-undangan menurut Pasal 1 angka 2 UU No. 12 Tahun 201 menentukan bahwa peraturan Perundang-undangan adalah peraturan tertulis yang memuat norma hukum yang mengikat secara umum dan dibentuk atau ditetapkan oleh lembaga negara atau pejabat yang berwenang melalui prosedur yang ditetapkan dalam Peraturan Perundangundangan. Berdasarkan definisi peraturan perundang-undangan di atas, maka sistem perundang-undangan di Indonesia adalah sistem yang harus melalui prosedur atau tahapan yang diatur dalam UU tentang Pembentukan Peraturan Perundang-undangan sebagai salah satu syarat keabsahan sebuah undangundang.

Namun, apabila merujuk kepada Pasal 10 ayat (1) UU No. 12 Tahun 2011 khususnya huruf e dinyatakan bahwa materi muatan undang-undang adalah "pemenuhan kebutuhan hukum dalam masyarakat", hal ini berarti segala sesuatu dapat diatur selama untuk "pemenuhan kebutuhan hukum dalam masyarakat" dan dibentuk bersama-sama oleh Presiden dan DPR. Kondisi ini menunjukan bahwa meskipun adanya keharusan melalui prosedur atau tahapan yang sesuai

${ }_{33}$ Adam M. Dodek, Omnibus Bills: Constitutional Constraints and Legislative Liberations, Ottawa Law Review Vol. 48, No. 1, 2017, hlm. 42.

${ }^{34}$ Ibid., hlm. 10

${ }^{35}$ Henry Campbell Black, Black's Law Dictionary: Definitions of The Terms and Phrases of American and English Jurisprudence, Ancient and Modern, West Publishing Co, St. Paul, 1968, hlm. 1239.

${ }^{36}$ Louis Massicotte, "Omnibus Bills in Theory and Practice”, Parliamentary Review Vol. 13, No. 1, 2013, hlm. 14-15. 
dengan UU tentang Pembentukan Peraturan Perundang-undangan namun masih dimungkinkan untuk menopang penggunaan metode omnibus. Setidak-tidaknya terdapat dua alasan penggunaan metode omnibus. Alasan pertama, yaitu terdapat tiga bentuk undang-undang apabila dikaitkan dengan UUD 1945, antara lain: ${ }^{37}$

1. Terdapat undang-undang yang menggabungkan 2 atau 3 materi muatan yang diatur dalam UUD.

2. Terdapat undang-undang yang dibentuk berdasarkan materi muatan yang ditentukan dalam UUD.

3. Terdapat undang-undang yang memperluas materi muatan yang diatur dari yang ditetapkan dalam UUD.

Kedua, bentuk kebijakan pembentuk undang-undang pada poin nomor 1 dan nomor 2, dipengaruhi dengan penggunaan rumusan frasa dalam UUD 1945, yakni "diatur dalam undang-undang" dan "diatur dengan undang-undang". Contoh diatur dengan undang-undang yaitu Pasal 6 ayat (2) UUD 1945, yang mengatur mengenai: Syarat-syarat untuk menjadi Presiden dan Wakil Presiden diatur lebih lanjut dengan undang-undang, dan Pasal 6A ayat (5) UUD 1945 yang mengatur "Tata cara pelaksanaan pemilihan Presiden dan Wakil Presiden lebih lanjut diatur dalam undang-undang", diatur digabungkan ke dalam satu undang-undang yaitu UU No. 42 Tahun 2008 tentang Pemilihan Umum Presiden Dan Wakil Presiden atau dalam konteks yang lebih luas yaitu UU No. 7 Tahun 2017 tentang Pemilu yang juga mengabungkan pemilihan DPR, DPD, dan DPRD. Contoh lainnya yang diatur dengan undang-undang yaitu Pasal 23C UUD 1945, yang menentukan "Hal-hal lain mengenai keuangan negara diatur dengan undang-undang", maka kemudian lahir Undang-Undang No. 17 Tahun 2003 tentang Keuangan Negara sebagai turunannya. Sedangkan pada nomor 3, terlihat pembentuk undangundang tidak memandang secara original intent dalam memahami teks UUD, melainkan memperluas makna, yang berdampak pada makin luasnya obyek yang diatur. Hal ini terdapat dalam, pertama, Undang-Undang No. 17 Tahun 2014 tentang MPR, DPR, DPD, DPRD (UU MD3), terdapat tambahanp engaturan DPRD. Padahal DPRD diatur dalam Pasal 18 ayat (3) UUD NRI Tahun 1945 pada Bab VI tentang Pemerintahan Daerah (Pemda). Jika dikaji dari konstruksi

${ }^{37}$ Jimmy Z. Usfunan, "Mengharmoniskan Undang-Undang Melalui Omnibus Law Model Indonesia, Prosiding, Konferensi Nasional Hukum Tata Negara Ke-4, 2017, Jember, Jawa Timur, Indonesia, hlm. 258. 
pengaturan, seharusnya kewenangan DPRD diatur dalam undang-undang tentang Pemerintahan Daerah. Kedua, ada perluasan makna "undang-undang" dari Pasal 22A menjadi "peraturan perundang-undangan" dalam UndangUndang No. 12 Tahun 2011 tentang Pembentukan Peraturan Perundangundangan. Berdasarkan analisis tersebut, UUD 1945 membolehkan pembentukan undang-undang yang materi muatannya lebih dari 1 obyek. Namun, isi materi yang diatur itu harus dimulai dari pembentukannya, bukan terjadi pada undangundang perubahannya.

Alasan kedua adalah eksistensi mekanisme asas preferensi hukum. Ketentuan Pasal 7 ayat (1) UU Pembentukan Peraturan Perundang-undangan ini menjelaskan bahwa kedudukan undang-undang itu sejajar. Akan tetapi terdapat asas preferensi hukum, yang telah dikenal luas dalam mengharmonisasikan peraturan perundang-undangan. Asas tersebut antara lain: (1) Asas lex superior derogate legiinferiori; (2) Asas lexspesialis derogate legigeneralis; (3) Asas lex posterior derogate legi priori. Sehingga apabila metode omnibus diterapkan dengan pola kodifikasi, penggunaan asas lex posterior derogate legi priori dapat digunakan untuk menjustifikasi yuridis teoritis. Dengan syarat menghilangkan anggapan bahwa suatu undang-undang yang mengunakan metode omnibus tidak sebagai lex generalis. Mekanisme ini dapat diterapkan, dengan mencabut ketentuan dalam undang-undang lainnya yang dianggap bertentangan, pada bagian ketemtuan penutup. Namun, apabila kemudian undang-undang yang melakukan kodifikasi aturan tidak mencabut beberapa ketentuan dalam undang-undang lainnya akan berpotensi dijadikannya perdebatan dalam impelementasinya, sehingga mengarah bertentangan dengan asas lex specialis derogate legigeneralis.

\section{Opsi Ideal Penggunaan Metode Omnibus}

Berdasarkan uraian di atas, menunjukan terdapat keterbatasan apabila menggunakan metode omnibus pada undang-undang di Indonesia. Kesimpulan semacam ini tidak hanya terjadi di Indonesia, bahkan melalui sebuah studi yang menjadi pendahuluan sebelum secara resmi di adopsinya metode omnibus di Vietnam, telah memberikan pertimbangan khusus (special consideration) tentang 
keterbatasan yang mungkin muncul apabila diadopsi ke dalam sistem perundang-undangan yang berbasis sistem hukum civil law, sebagai berikut: ${ }^{38}$

Although foreign experiences on the omnibus legislative technique have proved to be positive in implementing international trade agreements, foreign countries do have constitutional and legal frameworks, as well as history, culture and traditions which are different from those of Vietnam. Therefore, a special care and consideration of the factors that make the omnibus legislative technique work should be taken in studying foreign experiences before making appropriate proposals and recommendations for Vietnam. Any proposal or recommendation should ensure the feasibility and practicality in Vietnamese conditions, especially the applicability under the current law and practice on legislative works. Importantly, as foreign experiences show the omnibus legislative technique is not the only technique used to develop law and not the substitute for all current legislative techniques.

Oleh karena itu, pengadopsian memerlukan beberapa penataan dan menambahkan instrumen tambahan. Sependapat dengan Mirza Satria Buana dan Ekawestri Prajwalita Widiati, penataan dan penambahan instrumen yang dimaksud adalah mengkonstruksi hierarki perundang-undangan ulang dengan menambahkan undang-undang konsolidasi (consolidation law). ${ }^{39}$ Sejalan dengan Buana, eksistensi consolidation law diperlukan guna mengisi celah sistematisasi hukum perundang-undangan. ${ }^{40}$ Di Inggris, kebijakan reformasi hukum dimulai dari membentuk peraturan konsolidasi bahkan dikatakan sebagai prelude to law reform. ${ }^{41}$

Apabila merujuk secara definisi, consolidation law adalah "a collection or compilation into one statute or one code or volume of all the laws of the state in general, or of those relating to a particular subject; nearly the same as "compiled laws" or "compiled statutes." 42 Peraturan konsolidasi sendiri dapat dimaknai satu proses mengonsolidasikan beberapa peraturan perundang-undangan yang satu tema atau satu area ke dalam satu volume. ${ }^{43}$ Dalam consolidation, peraturan perundang-

\footnotetext{
38 Institute of Law Science, Study Paper: Possible Use Of The Omnibus Legislative Technique For Implemetation Of Vietnam's Wto Obligations And Commitments, The World Bank, 2006, hlm. 6-7.

${ }^{39}$ Mirza Satria Buana, "Menakar Konsep Omnibus Law Dan Consolidation Law Untuk Harmonisasi Peraturan Perundang-Undangan Indonesia: Pendekatan Perbandingan Hukum Tata Negara," Prosiding, Konferensi Nasional Hukum Tata Negara dan Hukum Administrasi Negara ke- 4, Jember, Indonesia, 2017 dan Ekawestri Prajwalita Widiati, Achieving Accessibility of Legislation via Consolidation, Masters thesis, Institute of Advanced Legal Studies, 2013.

${ }^{40}$ Ibid., hlm. 316.

${ }^{41}$ Ekawestri Prajwalita Widiati, Op. Cit., hlm. 22

${ }^{42}$ Henry Campbell Black, Op, Cit., hlm. 381

${ }^{43}$ Ekawestri Prajwalita Widiati, Op. Cit., hlm. 22
} 
undangan dipilah dan dikumpulkan dalam kluster sesuai dengan tema dimana tema itu sendiri ditentukan berdasarkan kebutuhan. Misalnya konsolidasi peraturan tentang pemerintahan daerah; maka semua saja aturan hukum yang mengatur pemerintahan daerah mulai dari peraturan yang tertinggi keperaturan di bawahnya diurutkan dan ditata pem-bab-annya menjadi satu volume khusus. ${ }^{44}$ Sehingga publik mendapatkan kemudahan apabila misalnya ingin mempelajari tata pemerintahan daerah tidak perlu melihat satu persatu peraturan tapi cukup dengan membaca peraturan konsolidasinya. Karena sifatnya yang informal, makasatu volume peraturan perundang-undangan yang lahirdari proses konsolidasi tidak menimbulkan keberlakuan yang baru. Proses konsolidasi bertujuan agar pembaca peraturan memahami logical sequence dari seperangkat aturan. Dengan kata lain proses ini juga berusaha menampakkan keberkaitan antara aturan satu dengan aturan yang lain dan aturan yang lebih tinggi terhadap peraturan pelaksananya dimana kesemua aturan itu sesungguhnya berada di tema yang sama.

Oleh karena itu, dalam konteks Indonesia, pengadopsian metode omnibus menurut penulis akan ideal apabila disertai penggunaan metode consolidation pasca lahirnya UU yang telah menggunakan metode omnibus. Metode consolidation akan berbentuk UU, namun bukan UU yang bersifat mengatur (regeling), melainkan hanya bersifat sebagai klarifikasi dan tafsir terhadap normanorma hukum dalam UU lain yang cenderung kontradiktif. Penafsiran dan klarifikasi lewat UU yang menggunakan metode konsolidasi, tidak hanya menjadi domain DPR, namun pemerintah juga wajib dilibatkan dan apabila materi terkait otonomi daerah, sehingga pelibatan DPD menjadi hal yang perlu. ${ }^{45}$ Konstruksi ini berkesesuaian dengan semangat yang dibangun pada Pasal 46 ayat (2), Pasal 47 ayat (3) dan Pasal 48 ayat (2) UU No 12 Tahun 2011 yang mana, ketiga pasal tersebut mensyaratkan perlunya pengharmonisasian, pembulatan, dan pemantapan konsepsi (rancangan) perundang-undangan baik yang berasal dari DPR, Pemerintah maupun DPD. Ini menjadi solusi yang penting mengingat metode consolidation saat ini telah dikembangkan oleh situs hukumonline.com

44Ibid., hlm. 23-24.

${ }^{45}$ Mirza Satria Buana, Op. Cit., hlm. 319. 
dan menjadi bisnis jasa mereka. Bahkan mereka mampu mengidentifikasi lebih dahulu terkait dengan keuntungan metode konsolidasi, antara lain:46

1. Menampilkan peraturan dan perubahan-perubahannya dalam satu naskah.

2. Dilengkapi anotasi putusan pengadilan yang dapat membatalkan atau memberikan tafsir terhadap pasal/ayat dalam peraturan.

3. Dilengkapi peraturan linear lain.

4. Selalu dimutakhirkan dengan perubahan terkini.

5. Format yang mudah digunakan.

6. Mempesingkat waktu riset hukum.

Apabila metode konsolidasi ini masuk ke dalam hierarki perundangundangan, maka kedudukannya yang ditempatkan sejajar atau setara dengan UU dan Perppu. Hal ini disebabkan UU Konsolidasi harus disusun secara bersamasama antara DPR dan Pemerintah, bahkan dalam hal terkait otonomi daerah, perlu melibatkan DPD. Kemudian interpretasi dan klarifikasi lembaga legislatifeksekutif dalam UU Konsolidasi tersebut dapat dimintakan uji materiil kepada MK. Dasar keberadaan dari UU Konsolidasi ini dapat menggunakan dalam asas peraturan perundang-undangan dalam Pasal 6 ayat 1 (i) dan (j) UU Pembentukan Peraturan Perundang-undangan yang mensyaratkan adanya ketertiban dan kepastian hukum dan/atau keseimbangan, keserasian, dan keselarasan dalam perundang-undangan.

Terlepas dari opsi sebagaimana terurai di atas, sejalan dengan Buana, penulis sependapat apabila metode omnibus lebih baik diletakkan pada Peraturan Presiden (Perpres). ${ }^{47}$ Perpres dapat lebih mengkonkritkan persoalan tumpang tindih peraturan perundang-undangan. Skema ini mendudukan bahwa relasi antara metode konsolidasi yang diletakkan pada tataran undang-undang dengan Perpres yang menggunakan omnibus bersifat atributif-hierarkis. Selain itu, UU Konsolidasi dan Perpres omnibus dapat mengharmoniskan norma-norma yang memiliki subyek area yang sama. Perpres omnibus dibuat sebagai manifestasi kebijakan publik pemerintah untuk menyelesaikan masalah-masalah disharmonisasi perundang-undangan dan pemenuhan kebutuhan hukum (legal needs) dalam masyarakat. Hal ini didasari oleh Pasal 13 UU No. 12 Tahun 2011

46 https://www.hukumonline.com/berita/baca/lt5d08a2d4ea4a8/peraturan-konsolidasi--mudahnyamembaca-peraturan-dan-perubahannya-hanya-dalam-1-naskah/, diakses tanggal 24 Maret 2020

${ }^{47}$ Mirza Satria Buana, Op. Cit., hlm. 319. 
tentang pembentukan peraturan perundang-undangan yang menentukan materi yang diperintahkan oleh Undang-Undang, materi untuk melaksanakan Peraturan Pemerintah, atau materi untuk melaksanakan penyelenggaraan kekuasaan pemerintahan. Konstruksi yang demikian ini sebenarnya juga telah di dorong oleh Jimly Asshiddiqie yang pernah memberikan saran untuk memberikan kewenangan khusus kepada Presiden lewat Perpres untuk mengharmonisasi peraturan perundangan- undangan. 48

\section{Rancangan Undang-Undang Cipta Kerja Sebagai Pilot Project}

Dalam konteks yang ada saat ini jelas berbeda dengan apa yang disampaikan di atas, yaitu metode omnibus akan gunakan pada tataran UU. RUU Cipta Kerja sebagai realisasi metode omnibus akan menggunakan dua model sekaligus yaitu meninjau undang-undang sejenis dan membuat materi baru serta mencabut aturan-aturan terkait sekaligus. Akibatnya, RUU Cipta Kerja memiliki spesifikasi "babon", yaitu 1.203 Pasal dengan 79 UU terdampak. Dari seluruh materi muatan RUU, terdapat pendelegasian lebih kurang 347 kali ke Peraturan Pemerintah. Terlepas hal itu semua, Peter Keyzer telah mengingatkan bahwa motivasi dan tindakan poin kedua akan memiliki kelemahan khususnya penggunaan metode omnibus, yaitu: (1) very difficult to draft, (2) limited opportunities for debate and scrutiny, (3) It may make consultation very difficult, (4) It may be hard to implement, (5) It can add to the complexity, rather than remove it. 49

RUU Cipta Kerja versi Surat Presiden Republik Indonesia Nomor: R06/Pres/02/2020 pada 7 Februari 2020 membawa motivasi pertumbuhan ekonomi, penciptaan lapangan kerja, daya saing dan inovasi. Akibatnya, pengaturan dalam RUU Cipta Kerja berpihak kepada peningkatan kapasistas ekonomi dengan cara memudahkan berinvestasi dan iklim kompetisi usaha di Indonesia. Berdasarkan hal tersebut, norma-norma yang muncul cenderung memudahkan ekspoitasi sumber daya, baik alam maupun manusia. Selain itu, pemangkasan izin-izin yang umumnya merupakan kewenangan daerah menjadi

\footnotetext{
48 Jimly Asshidiqie, Perihal Undang-Undang, Konstitusi Press, 2006, hlm. 227.

49 Patrick Keyzer, The Indonesian Omnibus Law: Opportunities and Challenges, Materi Kuliah Tamu, Universitas Brawijaya, Malang, 29 January 2020, hlm. 2.
} 
tersentralisasi ke pemerintah pusat melalui skema perizinan berusaha, berpotensi vis a vis dengan UU No. 23 Tahun 2014 tentang Pemerintahan Daerah.

Persoalan krusial lainnya adalah lahirnya Pasal 170 RUU Cipta Kerja yang memberikan kewenangan kepada pemerintah pusat untuk mengubah ketentuan dalam RUU Cipta Kerja (ketika sudah menjadi UU) serta ketentuan undangundang yang tidak diubah dalam RUU Cipta Kerja melalui Peraturan Pemerintah. Pasal ini bukan saja keliru dari segi ilmu perundang-undangan namun juga logika secara umum. Apabila memang sesungguhnya lahirnya RUU Cipta Kerja bertujuan untuk memperbesar kewenangan pemerintah dalam "revolusi" regulasi, mengapa tidak RUU Cipta Kerja langsung berisi seperti dalam Pasal 170, lalu kemudian menggunakan metode omnibus melalui instrumen peraturan pemerintah, atau perpres sekaligus saja. Hal lain yang menjadi banyak sorotan adalah penghapusan prinsip strict liabilty atau prinsip tanggung jawab mutlak dari ketentuan UU No. 32 Tahun 2009 tentang Perlindungan dan Pengelolaan Lingkungan Hidup. Prinsip tanggung jawab mutlak ini mewajibkan setiap pihak yang menggunakan, mengelola, menghasilkan atau mengolah B3 atau yang menimbulkan ancaman serius pada lingkungan untuk mempertanggungjawabkan tanpa harus dibuktikan adanya kesalahan. Terlepas, prinsip ini pernah dipersoalkan konstitusionalnya di Mahkamah Konstitusi, namun kemudian pemohon mencabut permohonan, namun prinsip ini dianut oleh banyak sekali negara dalam upaya melindungi lingkungan hidup. ${ }^{50}$

Terlepas dari motivasi dan persoalan diuraikan di atas, postur RUU Cipta Kerja dan beberapa paket RUU dengan metode serupa akan merombak total sistem perundang-undangan nasional. Pertama, berpotensi dilanggarnya asas keterbukaan, dalam pembentukan peraturan perundangan-undangan asas ini dimaknai bahwa dalam Pembentukan Peraturan Perundang-undangan mulai dari perencanaan, penyusunan, pembahasan, pengesahan atau penetapan, dan pengundangan bersifat transparan dan terbuka. Dengan demikian, seluruh lapisan masyarakat mempunyai kesempatan yang seluas-luasnya untuk

${ }^{50}$ Perkara Nomor 25/PUU-XV/2017 tentang pengujian Pasal 69 ayat (1) dan (2), Pasal 88, Pasal 99 UU Nomor 32/2009 juncto Pasal 49 UU Nomor 41/1999 yang diajukan oleh Asosiasi Pengusaha Hutan Indonesia (APHI) dan Gabungan Pengusaha Kelapa Sawit Indonesia (GAPKI) 
memberikan masukan dalam Pembentukan Peraturan Perundang-undangan. ${ }^{51}$ Tahap perencanaan dan penyusunan yang terkesan tertutup dan dipaksa untuk "ngebut" menjadi persoalan dan berpotensi mendapatkan pengujian formil dikemudian hari. Kedua, motivasi penyederhanaan dan perampingan regulasi yang dikehendaki justru berpotensi menggemuk di tataran di bawah UU khususnya Peraturan pemerintah yang mengemban beban 347 Delegasi kewenangan mengatur. Selain itu, persoalan jurang multitafsir menjadi lebar disebabkan materi pengaturan dari UU terdampak ternyata memiliki jiwa yang berbeda dengan materi didalam RUU Cipta Kerja, akibatnya ruang multitafsir membesar dan kemudian di uji kan ke Mahkamah Konstitusi? Apakah mungkin membenturkan antara UU terdampak dengan RUU Cipta Kerja?. Bagaimana ketika persoalan berada di bawah undang-undang yang lahir dari UU terdampak dihadapkan dengan UU metode omnibus atau PP yang lahir dari UU metode omnibus? Beban yang begitu besar pada PP dan jurang multitafsir akan mengakibatkan apa yang dikemukakan Peter Keyzer bahwa It may be hard to implement menjadi lebih relevan. Ketiga, kompleksitas norma RUU Cipta Kerja apabila dihadapkan dengan putusan MK. Apabila merujuk kepada kajian KODE Inisiatif terdapat 29 dari 79 UU terdampak pernah diujikan di Mahkamah Konstitusi. Selain itu, terdapat 54 putusan MK yang bertautan dengan undangundang yang diubah oleh RUU Cipta Kerja. KODE Inisiatif mencatat, terdapat 31 putusan MK yang tidak diindahkan oleh pemerintah dalam menyusun substansi RUU Cipta Kerja. ${ }^{52}$ Dari temuan tersebut, maka terdapat tiga polarisasi yang terjadi, yaitu, pertama, putusan MK tidak ditindaklanjuti di dalam RUU Cipta Kerja atau dengan kata lain, norma- norma yang telah dibatalkan atau ditafsirkan MK tidak diakomodasikan ke dalam RUU Cipta Kerja. Kedua, tindaklanjut terhadap putusan MK bersifat parsial atau hanya sebagian yang diakomodasikan di dalam RUU Cipta Kerja. Ketiga, munculnya pasal zombie atau pasal-pasal yang

\footnotetext{
${ }^{51}$ Penjelasan Pasal 5 huruf G UU No. 12 Tahun 2011 tentang Pembentukan Peraturan Perundangundangan

${ }^{52}$ KODE Inisiatif, Pasal-Pasal Inkonstitusional RUU Cipta Kerja, Kajian Singkat RUU Cipta Kerja, 5 Maret 2020, hlm. 2.
} 
telah dibatalkan oleh MK akibat bertentangan dengan UUD 1945 dihidupkan kembali oleh pemerintah di dalam RUU Cipta Kerja. ${ }^{53}$

Berdasarkan uraian di atas, penggunaan metode omnibus bukan perkerjaan yang mudah. Oleh karena itu, penulis mengusulkan beberapa instrumen tambahan yang bisa digunakan dalam meringankan proses adopsi dan adaptasinya. Pertama, dengan mengadakan UU Konsolidasi agar yang dimaksudkan untuk meningkatan akses pemahaman dan di saat yang bersamaan memberikan kejelasan norma termasuk yang dikaitkan dengan Putusan MK. Mekanisme ini bisa dilakukan sebelum dilakukan pembahasan terhadap RUU Cipta Kerja guna "memperlunak" proses adopsi metode omnibus atau sesudah lahirnya UU yang menggunakan metode omnibus, UU dengan metode konsolidasi akan dimaksudkan menghubungkan antara UU dengan metode omnibus dengan UU terdampak. Kedua, melakukan perubahan UU No. 12 Tahun 2011 tentang pembentukan peraturan perundang-undangan secara komprehensif untuk menyusun rambu-rambu dalam pengunaan metode omnibus dengan penekanan bagaimana pengaturan materi muatan seharusnya hingga bagaimana menyusun materi muatan peraturan pelaksananya. Ketiga, dalam tahapan pembahasan perlu dihindari disahkannya norma yang tidak menindaktindaklanjuti Putusan MK, tindaklanjut putusan MK yang bersifat parsial atau hanya sebagian dan menghindari munculnya pasal zombie.

\section{Penutup}

Proses instalasi metode omnibus ke dalam sistem peraturan perundangundangan tidak bisa dilakukan tanpa menimbang faktor sistem hukum, doktrin yang digunakan dalam sistem dan proses legislasi di Indonesia. Penerapan transplantasi hukum kontekstual harus dilakukan dengan mempertimbangkan faktor-faktor sebagaimana dikemukakan di atas. Penggunaan metode omnibus akan kompatibel apabila disertai dengan penggunaan metode konsolidasi. Terlepas penulis mengusulkan penggunaan metode omnibus ini pada taraf perpres dan metode konsolidasi pada taraf UU, namun bukan berarti penerapan metode omnibus seperti dalam RUU Cipta Kerja tidak memiliki jalan keluar untuk

${ }^{53}$ Ibid., hlm. 2-3. 
dapat terus menerapkannya. Penerapan metode konsolidasi pada undangundang sebelum atau pasca lahirnya UU dengan metode omnibus, apabila sebelum dimaksudkan sebagai dasar lahirnya UU dengan metode omnibus, atau setelah lahirnya UU dengan metode onmnibus dengan maksud mengklarifikasinya dengan UU terdampak. Selain itu, dengan melakukan perubahan UU No. 12 Tahun 2011 tentang pembentukan peraturan perundangundangan secara komprehensif untuk menyusun rambu-rambu pengunaan metode omnibus serta dengan dihindarinya norma yang tidak menindak lanjuti Putusan MK, tindaklanjut putusan MK yang bersifat parsial atau hanya sebagian dan menghindari munculnya pasal zombie, maka akan menciptakan landasan yang jauh lebih lunak dalam melahirkan UU dengan metode omnibus kedepannya.

\section{Daftar Pustaka}

Buku

Asshidiqie, Jimly, Perihal Undang-Undang, Konstitusi Press, Jakarta, 2006.

Black, Henry Campbell, Black's Law Dictionary: Definitions of The Terms and Phrases of American and English Jurisprudence, Ancient and Modern, West Publishing Co, St. Paul, 1968.

Cotterrell, Roger, The Politics of Jurisprudence: A Critical Introduction to Legal Philosophy, Oxford University Press, Oxford, 2003.

Damm, Jens, Leutner, Mechthild, Dayong, Niu, China's Interaction with the World: Historical and Contemporary Aspects, Lit Verlag, Zurich, 2017.

Indrati, Maria Farida, Ilmu Perundang-undangan: Proses dan Teknik Penyusunan, Kanisius, Yogyakarta, 2007.

Kelsen, Hans, The Pure Theory of Law, University of California Press, 1967.

Legrand, Pierre 'What Legal Transplants?, dalam Nelken, David dan Feest, Johannes (eds), Adapting Legal Cultures, Hart Publishing, Oxford, Portland, Oregon, 2001.

Massier, A.B., The Voice of the Law in Transition:Indonesian Jurists and Their Languages, 1915-2000, KITLV Press, Leiden,2008.

van der Vlies, I.C, Buku Pegangan Perancang Peraturan Perundang-Undangan, Direktorat Jenderal Peraturang Perundang-undangan, Jakarta, 2005.

Watson, Alan, Legal Transplant: an Approach to Comparative Law, University of Georgia Press, 1974.

Zweigert, Konrad dan Kötz, H., An Introduction of Comparative Law, Oxford University Press, Oxford, 1998. 


\section{Hasil Penelitian}

Institute of Law Science, Study Paper: Possible Use Of The Omnibus Legislative Technique For Implemetation Of Vietnam's Wto Obligations And Commitments, The World Bank, 2006.

\section{Jurnal}

Briffault, Richard, "The Single-Subject Rule: A State Constitutional Dilemma", Albany Law Review, Vol. 82 No. 4, 2019.

Chandranegara, Ibnu Sina, "Bentuk-Bentuk Perampingan dan Harmonisasi Regulasi," Jurnal Hukum Ius Quia Iustum, Vol. 26 No. 3, 2019.

Dodek, Adam M., “Omnibus Bills: Constitutional Constraints and Legislative Liberations", Ottawa Law Review, Vol. 48, No. 1, 2017.

Foster, Nicholas H.D, "Company Law Theory in Comparative Perspective: England and France", The American Journal of Comparative Law, Vol. 48, No. 4, 2000.

Gilbert, Michael D., "Single Subject Rules And The Legislative Process", University Of Pittsburgh Law Review, Vol. 67, No. 4, 2006.

Massicotte, Louis, "Omnibus Bills in Theory and Practice",Parliamentary Review Vol. 13, No. 1, 2013.

Ruud, Millard H. "No Law Shall Embrace More Than One Subject," Minnesota Law Review Vol. 42, No. 1, 1958.

Tushnet, Mark, "The Possibilities of Comparative Law", Yale Law Review 108, 1999.

Watson, Allan, "Aspects of Reception of Law", The American Journal of Comparative Law Vol. 44. 1996.

, "Legal Change: Sources of Law and Legal Culture", University of Pennsylvania Law Review, Vol. 131, No. 5. 1983.

,"Society and Legal Change", Michigan Law Review Vol. 78, No. 5, 1980.

\section{Disertasi/Tesis}

Attamimi, A. Hamid S., "Peranan Keputusan Presiden Republik Indonesia dalam Penyelenggaraan Pemerintahan Negara: Suatu Studi Analisis Mengenai Keputusan Presiden yang Berfungsi Pengaturan Dalam Kurun Waktu PELITA I-PELITA IV", Disertasi, Fakultas Hukum Universitas Indonesia, 1990.

Dejonghe Matthias, "Constitutional Courts: Democracy vs. Juristocracy?" Disertasi, Fakultas Hukum Universitas Genht, Brussel, 2015.

Widiati, Ekawestri Prajwalita, "Achieving Accessibility of Legislation via Consolidation." Masters thesis, Institute of Advanced Legal Studies, 2013.

\section{Makalah/Pidato}


Asshiddiqie, Jimly, UU Omnibus (Omnibus Law), Penyederhanaan Legislasi, dan Kodifikasi Administratif, tanpa tahun, tanpa penerbit.

Attamimi, A. Hamid S., Ilmu Pegetahuan Perundang- Undangan (Gesetzgebungswissenchaft) Dan Pengembangan Pengajarannya Di Fakultas Hukum, Makalah dalam Diskusi Mengenai Kemungkinan Masuknya Ilmu Perundang-undangan Dalam Kurikulum Fakultas Hukum pada Penemuan Dekan-Dekan Fakultas Hukum Negeri Se-Indonesia di Bawah Konsorsium Ilmu Hukum, Jakarta, 20-21 Oktober 1989.

Buana, Mirza Satria, "Menakar Konsep Omnibus Law Dan Consolidation Law Untuk Harmonisasi Peraturan Perundang-Undangan Indonesia: Pendekatan Perbandingan Hukum Tata Negara", Prosiding, Konferensi Nasional Hukum Tata Negara Ke-4, Jember, Jawa Timur, Indonesia, 2017.

Farrel, John, Better Regulation in the UK, Presentasi Makalah OECD, 2015.

Giorgio Bongiovanni, "Rechsstaat and Grundnorm in the Kelsenian Theory", dalam Marijan Pavčnik dan Gianfransesco Zanetti, Legal System and Legal Science. Proceeding, 17thWorld Congress of The International Association For Philosophy of Law and Social Philosophy, Bologna, Italy, 16- 21 June 1995.

Indrati, Maria Farida, Dapatkah Undang-Undang Omnibus Menyelesaikan Masalah Tumpang Tindihnya Undang-Undang?, Bahan Rapat Dengar Pendapat Umum Badan Legislasi DPR-RI, 2 Desember 2020.

Keyzer, Patrick, The Indonesian Omnibus Law: Opportunities and Challenges, Materi Kuliah Tamu, Universitas Brawijaya, Malang, 29 January 2020.

KODE Inisiatif, Pasal-Pasal Inkonstitusional Ruu Cipta Kerja, Kajian Singkat RUU Cipta Kerja, 5 Maret 2020.

Redi, Ahmad, Omnibus Law Gasasan Pengaturan untuk Kemakmuran Rakyat. Bahan Presentasi Diskusi Kolegium Jurist Institute, Rambu-Rambu Konstitusi dalam Wacana Omnibus Law, Jakarta, 5 Maret 2020.

Setiadi, Wicipto, Simplifikasi Regulasi Melalui Pendekatan Omnibus Law: Suatu Keniscayaan, Orasi Ilmiah Dalam Rangka Dies Natalis Universitas Pembangunan Nasional “Veteran” Jakarta Ke-57, 7 Januari 2020.

Shimada, Yuzuru, "Strategy and Regulatory Reform Practices in Japan: Harmonization of Central and Local Regulations in The Era of Local Autonomy", Prosiding, Konferensi Nasional Hukum Tata Negara Ke-4, Jember, Jawa Timur, Indonesia, 2017.

Umar, Bobby Gafur, Omnibus Law guna Menjawab Tantangan dan Peluang Pertumbuhan Ekonomi, Makalah dalam Seminar Dies Natalis Fakultas Hukum UGM, 13 Februari 2020.

Usfunan, Jimmy Z., "Mengharmoniskan Undang-Undang Melalui Omnibus Law Model Indonesia", Prosiding, Konferensi Nasional Hukum Tata Negara Ke-4, Jember, Jawa Timur, Indonesia, 2017. 


\section{Artikel Koran}

Koran Sindo, 5 November 2019, Wicipto Setiadi, “Menggagas Undang-Undang Sapu Jagat".

\section{PeraturanPerundang-undangan}

Undang-Undang Nomor 12 Tahun 2011 Tentang Pembentukan Peraturan Perundang-undangan, Lembaran Negara Republik Indonesia Tahun 2011 Nomor 82, Tambahan Lembaran Negara Republik Indonesia Nomor 5234.

Peraturan Pemerintah Pengganti Undang-Undang Republik Indonesia Nomor 1 Tahun 2020 Tentang Kebijakan Keuangan Negara Dan Stabilitas Sistem Keuangan Untuk Penanganan Pandemi Corona Virus Disease 2019 (Covid-19) dan/atau Dalam Rangka Menghadapi Ancaman Yang Membahayakan Perekonomian Nasional Dan/Atau Stabilitas Sistem Keuangan (Lembaran Negara Republik Indonesia Tahun 2020 Nomor 8, Tambahan Lembaran Negara Republik Indonesia Nomor 6485)

RancanganUndang-UndangTentangCiptaKerjaversi Surat PresidenRepublik Indonesia Nomor: R-06/Pres/02/2020 Tanggal 7 Februari 2020. 